\title{
Griginal Mismatch repair protein expression in periampullary carcinoma
}

\author{
Niraj Kumari ${ }^{1}$, Pooja Shukla ${ }^{1}$, Rajneesh Kumar Singh ${ }^{2}$, \\ Narendra Krishnani ${ }^{1}$
}

${ }^{1}$ Department of Pathology, ${ }^{2}$ Department of Surgical Gastroenterology, Sanjay

Gandhi Postgraduate Institute of Medical

Sciences, Lucknow, India.

Correspondence: Narendra Krishnani

Email:narendrakrishnani@yahoo.co.in

\section{ABSTRACT}

Introduction: Mismatch repair (MMR) protein expression has become the screening test of microsatellite instability (MSI). The literature is limited on the expression of MMR proteins in periampullary carcinoma (PC). We studied MMR expression in PC and its correlation with histological differentiation and clinicopathological parameters.

Methods: All consecutive PC specimens received within 3 years duration were classified as intestinal, pancreatobiliary and other types using morphological criteria and IHC (CDX2, MUC1, MUC2, CK17). MMR expression was studied using MLH1, MSH2, MSH6 and PMS2. MMR expression loss was correlated with histological parameters using chisquare test and survival analysis was done by Kaplan Meier using log-rank test.

Results: Overall expression loss of MMR proteins was 8.3\% $(9.7 \%$ in intestinal, $7.4 \%$ in pancreatobiliary). The histopathological parameters were largely similar in cases with MMR loss and intact expression. Median survival was also similar between the two groups (median survival of 29 months Vs. 28 months in patients with MMR expression loss and intact expression respectively)

Conclusion: Overall expression loss of MMR proteins was $8.3 \%$ with $9.7 \%$ in intestinal and $7.4 \%$ in pancreatobiliary type. Histological differentiation was superior to MMR expression loss in predicting prognosis in PC.

KEYWORDS: MMR proteins; periampullary cancer; mismatch repair proteins; prognosis.

\section{Introduction}

Periampullary carcinoma (PC) is a heterogeneous group of cancers that includes ampullary, pancreatic head, distal bile duct and duodenal cancers. The incidence of these cancers in resected pancreato-duodenectomies varies in different parts of the world with pancreatic head cancer being the most common in the west (5\% to $25 \%) \cdot{ }^{1-5}$ In 
the Indian population, the ampullary carcinoma forms the bulk. $^{6-7}$

Expression of mismatch repair (MMR) proteins is the first line screening test for detecting microsatellite instability (MSI). MSI is one of the important pathogenetic mechanisms in Lynch syndrome. Studies investigating the prognostic value of microsatellite instability (MSI) in PC that have shown that tumors with MSI show significantly longer 5 year survival and better prognosis than those with low MSI (MSI-L) or microsatellite stable (MSS) tumors. ${ }^{8-9}$ MSI is responsible for $15 \%-20 \%$ of colorectal cancer and a similar percentage of periampullary cancers have been shown to have MSI. ${ }^{10}$ The incidence of MSI in periampullary carcinoma reported in literature varies widely from $0 \%$ to $22 \%$ in different studies using different methodologies. Intestinal type PC have shown to be associated more frequently with MSI than pancreatobiliary type PCs. ${ }^{8}$

The present study was planned to evaluate MMR protein expression as a marker for MSI in periampullary carcinoma and to correlate the loss of expression with its anatomical and histological subtypes and clinicopathological factors.

\section{Methods}

One hundred and eight consecutive cases of PC were retrieved retrospectively within a period of three years. All the cases were histologically classified into intestinal, pancreatobiliary, mixed or other types using a combination of morphological criteria given by Albores-Saavedra et $\mathrm{al}^{11}$ and panel of IHC markers. The markers used for pancreatobiliary differentiation were MUC1 (polyclonal, dilution 1:50, Thermoscientific), CK17 (clone E3, dilution 1:40, Thermoscientific) and CK7 (clone OV-TL 12/30, dilution 1:80, Dako); and for intestinal differentiation were MUC2 (clone Ccp58, dilution 1:100, Novocastra), CDX2 (clone MU392A.UC, dilution 1:50, Biogenex) and CK20 (clone Ks20.8, dilution 1:8, Dako). IHC for MMR proteins included MLH1 (clone ES05, Novocastra, dilution 1:25), MSH2 (clone 25D12, Novocastra, 1:50), MSH6 (clone PU29, Novocastra, dilution 1:50) and PMS2 (clone EP51, DAKO, dilution 1:40). Antigen retrieval was done by microwave treatment using the EZ Antigen retriever (Biogenex). This was done in citrate buffer at pH 6.0 for MUC1, MUC2, MLH1, MSH2, MSH6 and CK17 and in EDTA buffer at pH 8.0 for CDX2, CK7, CK20 and PMS2 for 30 minutes. Sections were incubated with primary antibody at room temperature for one hour followed by secondary antibody (Dako LSAB Envision Universal kit) for 30 minutes at room temperature. Diaminobenzidine (DAB) was used as the chromogen. The slides were washed and counterstained with Mayer's hematoxylin. MMR expression was considered lost only when there was a complete absence of nuclear staining in the presence of a positive control.

\section{Statistical Analysis}

Correlation of expression loss and intact expression of MMR proteins with different histological parameters were analyzed using chi-square test and survival analysis between these two groups was done using Kaplan Meier curves using log-rank test. Probability ( $p$ ) values of $<0.05$ obtained by the two tailed significance were regarded as statistically significant. SPSS software program, version 15 was used for all statistical analyses.

\section{Results}

Ampullary cancers accounted for $91(84.2 \%)$ cases of the 108 periampullary carcinomas. Carcinoma head of pancreas constituted another 9 (8.3\%), distal CBD cancers $5(4.6 \%)$ and duodenal cancers $3(2.7 \%)$ cases. Using morphological criteria and IHC markers, 41 (38\%) cases were classified as intestinal type, 54 (50\%) cases as pancreatobiliary type, $6(5.6 \%)$ cases as mixed type and $7(6.5 \%)$ cases were put in the category of others type (Table 1). Overall expression loss of MMR proteins was seen in $9(8.3 \%)$ cases (Figure 1 a-e). The pattern of MMR protein loss is shown in Table 2. Among the histological types, loss of MMR protein was equally distributed between intestinal and pancreatobiliary types with 4 cases each and one case was of signet ring cell carcinoma. 6 of the patients with loss of MMR expression were male. There was no significant correlation between MMR expression loss and clinicopathological parameters in periampullary carcinoma (Table 3). The MMR expression 
loss was then correlated with histological differentiation. The intestinal type tumors with loss of MMR protein had tendency to have low grade, less lymphovascular invasion, low T-stage and low overall TNM stage (Table 4), however the difference was not found to be statistically significant. The pancreatobiliary tumors with loss of MMR protein expression on the other hand had a tendency for higher grade, more perineural invasion, earlier lymph node metastasis, higher T-stage and higher overall TNM stage (Table 4), however again the differences were not statistically significant.

The follow-up period ranged from 1 month to 64 months (median 20 months). The median survival in patients with loss of MMR protein was 29 months (95\% CI $=2.02-55.9$ months) whereas in patients with intact expression of MMR protein it was 28 months, (95\% $\mathrm{CI}=17.2-38.7$ months) with a $\mathrm{p}$ value of 0.06 (Figure 2 a-d). In intestinal type, the median survival was not computable however mean survival was 52.7 months (95\% CI -41.0 to 64.4 months) in patients with intact MMR expression and 21.6 months (95\% CI-16.3 to 27.0 months) in patients with MMR loss. In pancreatobiliary type of PC the median survival was little higher in patients with intact MMR expression (20 months, 95\% CI-13.2 to 26.7 months) compared to patients MMR loss (14 months, 95\% CI- 0.0 to 34.5 months) (p value -0.01 ) (Figure 2 a-d).

\section{Discussion}

Different studies have found variable rates of MSI or loss of MMR expression in periampullary cancers, ranging from $0 \%$ to $22 \%{ }^{8,12-16}$ This may be attributed

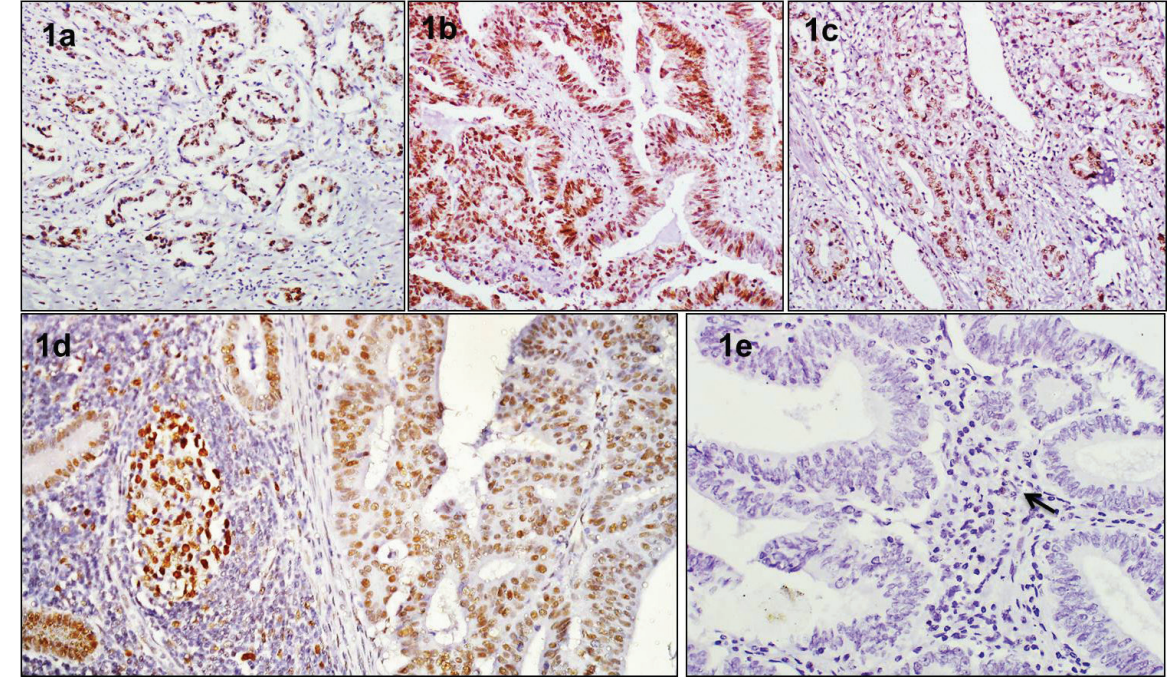

Figure 1: Immunohistochemistry for MMR proteins shows (a): MLH1 (b): MSH2 (c): PMS2 and (d): MSH6 in periampullary carcinoma. Loss of MMR expression in tumor with staining of intratumoral lymphocytes (e) is seen as internal control (arrow). (Immunohistochemistry; X40 magnification).

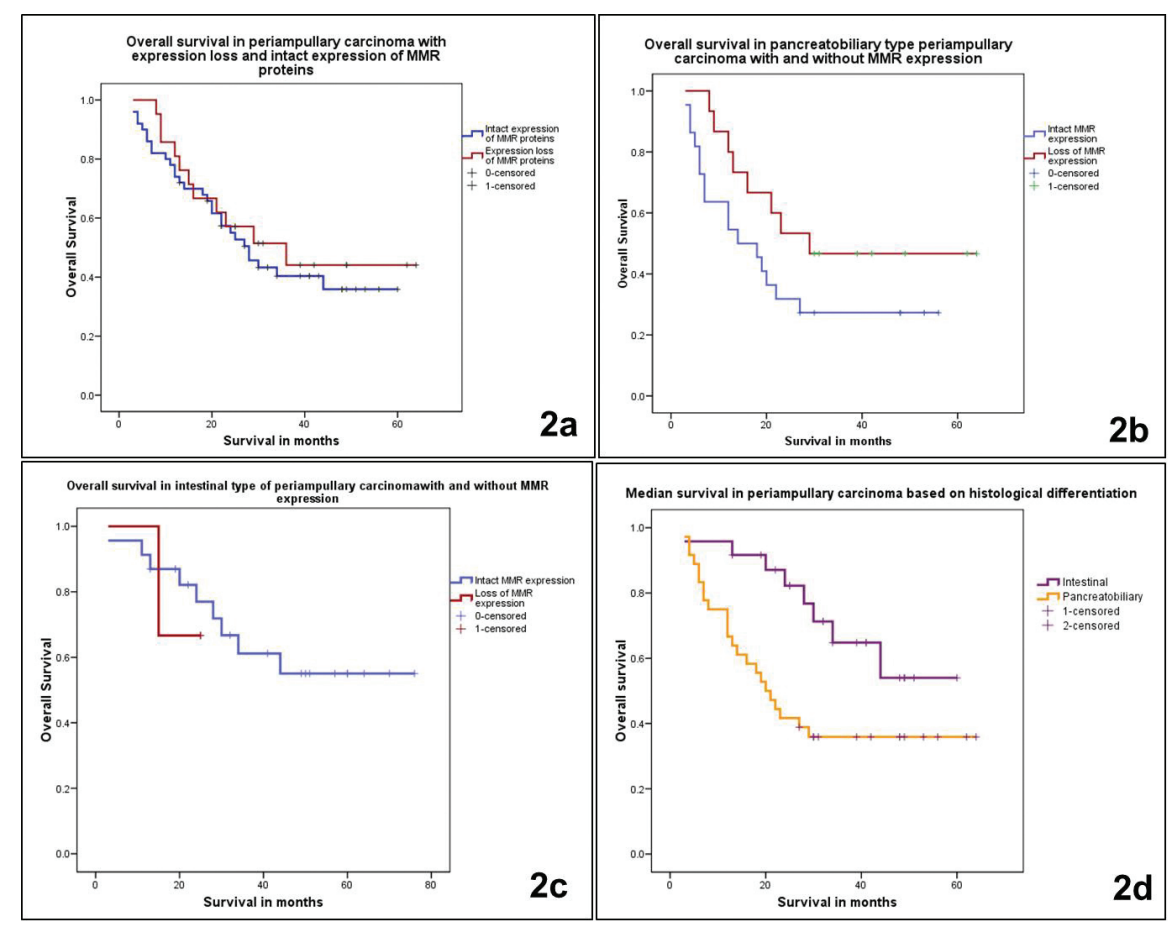

Figure 2: (a): Overall survival curves between expression loss and intact expression of MMR proteins in periampullary carcinoma. (b): Survival difference between expression loss and intact expression of MMR proteins in pancreatobiliary type of periampullary carcinoma. (c): Survival difference between expression loss and intact expression of MMR proteins in intestinal type of periampullary carcinoma. (d): Survival difference between intestinal and pancreatobiliary differentiation in periampullary carcinoma irrespective of MMR loss or intact expression. 
to the difference in methodologies used for MSI analysis, although the sensitivity of $92 \%$ and specificity of $99 \%$ for IHC to detect MSI in colorectal carcinoma has been shown in different studies. ${ }^{18-20}$ It can also be explained by the different anatomic locations studied in different series. The role of MSI in periampullary carcinoma also varies with some studies reporting to have no relation with clinicopathological parameters whereas others show association with a better prognosis. Achille et al found MSI of about $20 \%$ in a series of 25 cases of ampullary carcinoma and reported a significant association between
Table 1: Distribution of histological subtypes of periampullary cancer using morphology and immunohistochemistry

\begin{tabular}{l|c}
$\begin{array}{l}\text { Histological } \\
\text { subtypes }\end{array}$ & $\begin{array}{l}\text { Periampullary carcinoma } \\
(\mathbf{n}=\mathbf{1 0 8})\end{array}$ \\
\hline Intestinal & 41 \\
\hline Pancreatobiliary & 54 \\
\hline Mixed & 6 \\
\hline Adenosquamous & 2 \\
\hline Signet ring cell & 3 \\
\hline Undifferentiated & 2
\end{tabular}

Table 2: Expression loss of mismatch repair proteins in different histological subtypes of periampullary carcinoma $(\mathrm{n}=108)$

\begin{tabular}{l|c|c|c|c|c|c|c}
$\begin{array}{l}\text { MMR protein } \\
\text { expression loss }\end{array}$ & $\begin{array}{c}\text { Intestinal } \\
\mathbf{( 4 1 )}\end{array}$ & $\begin{array}{c}\text { Pancreato- } \\
\text { biliary (54) }\end{array}$ & Mixed (6) & $\begin{array}{c}\text { Adeno- } \\
\text { squamous (2) }\end{array}$ & $\begin{array}{c}\text { Signet ring } \\
\text { cell (3) }\end{array}$ & $\begin{array}{c}\text { Undifferen- } \\
\text { tiated (2) }\end{array}$ & $\begin{array}{c}\text { Total } \\
(\mathbf{1 0 8 )}\end{array}$ \\
\hline MLH1+PMS2 & 3 & 1 & 0 & 0 & 1 & 0 & 5 \\
\hline MSH2+MSH6 & 1 & 2 & 0 & 0 & 0 & 0 & 3 \\
\hline MSH6 & 0 & 1 & 0 & 0 & 0 & 0 & 1 \\
\hline Total & $\mathbf{4 ( 9 . 7 \% )}$ & $\mathbf{4 ( 7 . 4 \% )}$ & $\mathbf{0}$ & $\mathbf{0}$ & $\mathbf{1 ( 3 3 . 3 \% )}$ & $\mathbf{0}$ & $\mathbf{9 ( 8 . 3 \% )}$
\end{tabular}

Table 3: Distribution of histological prognostic parameters in periampullary carcinoma with loss and intact expression of MMR proteins $(\mathrm{n}=108)$

\begin{tabular}{|c|c|c|c|}
\hline Parameters & $\begin{array}{c}\text { Expression loss of MMR } \\
\text { protein }(\mathrm{n}=9)\end{array}$ & $\begin{array}{c}\text { Intact expression of MMR } \\
\text { protein }(n=99)\end{array}$ & P value \\
\hline Male : Female & $6: 3$ & $68: 31$ & 0.9 \\
\hline Histological grade & & & 0.07 \\
\hline Grade I & $4(44.4 \%)$ & $61(61.6 \%)$ & \\
\hline Grade II & $2(22.2 \%)$ & $29(29.3 \%)$ & \\
\hline Grade III & $3(33.3 \%)$ & $7(7.1 \%)$ & \\
\hline Grade IV (Undifferentiated) & 0 & $2(2 \%)$ & \\
\hline Perineural Invasion & $5(55.5 \%)$ & $42(42.4 \%)$ & 0.4 \\
\hline Lymphovascular invasion & $1(11.1 \%)$ & $20(20.2 \%)$ & 0.5 \\
\hline T stage & & & 0.9 \\
\hline $\mathrm{T} 1$ & $3(33.3 \%)$ & $36(36.78 \%)$ & \\
\hline $\mathrm{T} 2$ & $3(33.3 \%)$ & $34(34.3 \%)$ & \\
\hline \multirow[t]{2}{*}{$\mathrm{T} 3$} & $3(33.3 \%)$ & $28(28.3 \%)$ & \\
\hline & & 1 & \\
\hline Nodal metastasis & $5(55.5 \%)$ & $42(42.4 \%)$ & 0.3 \\
\hline TNM Stage & & & 0.7 \\
\hline Stage I & $3(33.3 \%)$ & $41(41.4 \%)$ & \\
\hline \multirow[t]{2}{*}{ Stage II } & $6(66.6 \%)$ & $55(55.5 \%)$ & \\
\hline & 0 & 2 & \\
\hline $\begin{array}{l}\text { Histological differentiation } \\
\text { Intestinal : Pancreatobiliary }\end{array}$ & $4: 4$ & $37: 50$ & 0.6 \\
\hline
\end{tabular}


Table 4: Distribution of histological prognostic parameters in intestinal and pancreatobiliary subtypes of periampullary carcinoma with loss and intact expression of MMR proteins $(n=9)$

\begin{tabular}{|c|c|c|c|c|c|c|}
\hline \multirow[b]{2}{*}{ Parameters } & \multicolumn{3}{|c|}{ Intestinal Type PC $(n=41)$} & \multicolumn{3}{|c|}{ Pancreatobiliary Type PC $(\mathrm{n}=54)$} \\
\hline & $\begin{array}{l}\text { Expression loss } \\
\text { of MMR protein } \\
\quad(n=4)\end{array}$ & $\begin{array}{l}\text { Intact expression } \\
\text { of MMR protein } \\
(\mathrm{n}=\mathbf{3 7})\end{array}$ & P value & $\begin{array}{l}\text { Expression loss } \\
\text { of MMR protein } \\
\quad(n=4)\end{array}$ & $\begin{array}{l}\text { Intact expression } \\
\text { of MMR protein } \\
\qquad(\mathrm{n}=\mathbf{5 0})\end{array}$ & P value \\
\hline Male : Female & $2: 2$ & $26: 11$ & 0.4 & $3: 1$ & $33: 17$ & 0.7 \\
\hline Histological grade & & & 0.1 & & & 0.4 \\
\hline Grade I & $3(75 \%)$ & $29(78.4 \%)$ & & $1(25 \%)$ & $26(52 \%)$ & \\
\hline Grade II & 0 & $7(19 \%)$ & & $2(50 \%)$ & $20(40 \%)$ & \\
\hline Grade III & $1(25 \%)$ & $1(2.7 \%)$ & & $1(25 \%)$ & $3(6 \%)$ & \\
\hline $\begin{array}{l}\text { Grade IV } \\
\text { (Undifferentiated) }\end{array}$ & 0 & $2(5.4 \%)$ & & & $1(2 \%)$ & \\
\hline $\begin{array}{l}\text { Perineural } \\
\text { Invasion }\end{array}$ & $1(25 \%)$ & $8(21.6 \%)$ & 0.8 & $3(75 \%)$ & $30(60 \%)$ & 0.5 \\
\hline $\begin{array}{l}\text { Lymphovascular } \\
\text { invasion }\end{array}$ & 0 & $3(8.1 \%)$ & 0.5 & $1(25 \%)$ & $15(30 \%)$ & 0.8 \\
\hline T stage & & & 0.8 & & & 0.3 \\
\hline $\mathrm{T} 1$ & $2(50 \%)$ & $17(46 \%)$ & & $1(25 \%)$ & $15(30 \%)$ & \\
\hline $\mathrm{T} 2$ & $2(50 \%)$ & $15(40.5 \%)$ & & 0 & $15(30 \%)$ & \\
\hline \multirow[t]{2}{*}{$\mathrm{T} 3$} & & $4(10.8 \%)$ & & $3(75 \%)$ & $20(40 \%)$ & \\
\hline & & $1(2.7 \%)$ & & & & \\
\hline Nodal metastasis & $1(25 \%)$ & $11(29.7 \%)$ & 0.7 & $3(75 \%)$ & $25(50 \%)$ & 0.09 \\
\hline TNM Stage & & & 0.8 & & & 0.1 \\
\hline Stage I & $3(75 \%)$ & $22(59.4 \%)$ & & 0 & $15(30 \%)$ & \\
\hline \multirow[t]{2}{*}{ Stage II } & $1(25 \%)$ & $14(37.8 \%)$ & & $4(100 \%$ & $35(70 \%)$ & \\
\hline & 0 & $1(2.7 \%)$ & & & & \\
\hline
\end{tabular}

MSI and longer patient survival. ${ }^{12}$ Imai et al reported a high rate of MSI $(22.2 \%)$ and markedly frequent alteration of the TGF-b-receptor-II gene (77.8\%) in ampullary carcinomas. ${ }^{13}$ Using PCR, Scarpa et al found $15.1 \%$ and Suto et al found $12.5 \%$ of ampullary carcinoma showed MSI. ${ }^{14-15}$ Ruemmele et al found a sensitivity of $79 \%$ and a specificity of $100 \%$ for predicting MSI in ampullary carcinoma using MLH1, MSH2 and MSH6 immunostaining. They noticed 10\% (14 cases) MSI-H in 144 ampullary adenocarcinoma and $7 \%$ in adenoma which was accompanied by loss of MMR protein in $79 \%$ and $50 \%$ cases respectively and concluded that MSI occurs as an early event at the stage of adenoma. They found that ampullary carcinoma with MSI had significantly longer survival and better prognosis than those with MSI-L or MSS cancers. ${ }^{8}$ Eleven of 15 cases were intestinal type, 3 were pancreatobiliary type and one case was of invasive papillary carcinoma. They found tumor grade, histologic subtype and survival to be significant correlated with MSI status on univariate analysis and only tumor grade and survival on multivariate analysis. Sessa et al showed MSI-H in 5 (9.5\%) of 53 cases of ampullary carcinoma of whom all were of intestinal type and half were associated with mucinous or medullary component similar to colon cancer. ${ }^{9}$ In their study MSI status significantly affected survival on univariate analysis although it was not significant in multivariate analysis. Park et al and Rashid et al did not find MSI in any of their cases of ampullary carcinoma. ${ }^{16-17}$ Suto et al reported MSI-H in $12.5 \%$ cases of ampullary carcinoma and did not find any correlation of clinicopathological parameters with MSI status. ${ }^{15}$ 
In the present study rate of loss of MMR protein in periampullary carcinoma (8.3\%) was similar to those reported in the literature. The MMR expression loss in PC did not show any correlation with clinicopathological parameters. However, when it was correlated with histological differentiation, intestinal type with MMR loss featured better than pancreatobiliary with MMR loss. Since histological differentiation of intestinal and pancreatobiliary in periampullary carcinoma remains the key determinant for predicting prognosis, this finding holds little value. This is reiterated in the fact that the survival as well where median survival in periampullary carcinoma was marginally higher in cases with MMR but this difference disappeared when histological types were considered.

\section{Conclusion}

Microsatellite instability is one of the important pathogenetic mechanisms in carcinogenesis. However, the present study did not find any evidence to suggest that it may impact the prognosis in any way. The difference in prognostic parameters in periampullary carcinoma were influenced by histological differentiation of intestinal and pancreatobiliary type rather than expression loss of MMR proteins.

\section{References}

1. Sarmiento JM, Nagomey DM, Sarr MG, Farnell MB. Periampullary cancers: are there differences? Surg Clin North Am. 2001;8:543-555.

2. Yeo CJ, Cameron JL, Sohn TA, Lillemoe KD, Pitt HA, Talamini MA, et al. Six hundred fifty consecutive pancreaticoduodenectomies in the 1990s: pathology, complications, and outcomes. Ann Surg. 1997;226:248257.

3. Lowe MC, Coban I, Adsay NV, Sarmiento JM, Chu $\mathrm{CK}$, Staley CA, et al. Important prognostic factors in adenocarcinoma of the ampulla of Vater. Am Surg. 2009;75:754-760.

4. Howe JR, Klimstra DS, Moccia RD, Conlon KC, Brennan MF. Factors predictive of survival in ampullary carcinoma.
Ann Surg. 1998;228:87-94.

5. Carter JT, Grenert JP, Rubenstein L, Stewart L, Way LW. Tumors of the ampulla of vater: histopathologic classification and predictors of survival. J Am Coll Surg. 2008;207:210-218.

6. Balachandran P, Sikora SS, Kapoor S, Krishnani N, Kumar A, Saxena R, et al. Long-term survival and recurrence patterns in ampullary cancer. Pancreas. 2006;32:390-395.

7. Kumari N, Prabha K, Singh RK, Baitha DK, Krishnani N. Intestinal and pancreatobiliary differentiation in periampullary carcinoma: the role of immunohistochemistry. Human Pathology. 2013;44:22132219.

8. Ruemmele P, Dietmaier W, Terracciano L, Tornillo L, Bataille F, Kaiser A, et al. Histopathologic features and microsatellite instability of cancers of the papilla of vater and their precursor lesions. Am J Surg Pathol. 2009;33:691704.

9. Sessa F, Furlan D, Zampatti C, Carnevali I, Franzi F, Capella C. Prognostic factors for ampullary adenocarcinomas: tumor stage, tumor histology, tumor location, immunohistochemistry and microsatellite instability. Virchows Arch. 2007;451:649-657.

10. Agaram NP, Shia J, Tang LH, Klimstra DS. DNA mismatch repair deficiency in ampullary carcinoma: a morphological and immunohistochemical study of 54 cases. Am J Clin Pathol. 2010;133:772-780.

11. Albores-Saavedra J, Menck HR, Scoazec JC, Soehendra C. Wittekind P.V.J. Sriram B, et al. Carcinoma of the gallbladder and extrahepatic bile ducts. In. Hamilton SR, Aaltonen LA, Ed. WHO Classification of Tumours Pathology and Genetics of the Digestive System. Lyon: IARC Press: 2000;204-217.

12. Achille A, Biasi MO, Zamboni G, Bogina G, Iacono C, Talamini G, et al. Cancers of the papilla of vater: mutator phenotype is associated with good prognosis. Clin Cancer Res. 1997;3:1841-1847.

13. Imai $Y$, Tsurutani $N$, Oda $H$, Inoue $T$, Ishikawa $T$. Genetic instability and mutation of the TGF-beta-receptor-II gene in ampullary carcinomas. Int J Cancer. 1998;76:407-411.

14. Scarpa A, Di Pace C, Talamini G, Falconi M, Lemoine NR, Iacono $\mathrm{C}$, et al. Cancer of the ampulla of Vater: chromosome $17 \mathrm{p}$ allelic loss is associated with poor prognosis. Gut. 2000;46:842-884.

15. Suto T, Habano W, Sugai T, Uesugi N, Kanno S, Saito K, et al. Infrequent microsatellite instability in biliary tract cancer. J Surg Oncol. 2001;76:121-126. 
16. Park S, Kim SW, Kim SH, Darwish NS, Kim WH. Lack of microsatellite instability in neoplasms of ampulla of Vater. Pathol Int. 2003;53:667-670.

17. Rashid A, Ueki T, Gao YT, Houlihan PS, Wallace C, Wang BS, et al. K-ras mutation, p53 overexpression, and microsatellite instability in biliary tract cancers: a population-based study in China. Clin Cancer Res. 2002;8:3156-3163.

18. Shia J, Klimstra DS, Nafa K, Offit K, Guillem JG, Markowitz AJ, et al. Value of immunohistochemical detection of DNA mismatch repair proteins in predicting germline mutation in hereditary colorectal neoplasms. $\mathrm{Am}$ J Surg Pathol. 2005;29:96-104.

19. Shia J, Ellis NA, Klimstra DS. The utility of immunohistochemical detection of DNA mismatch repair gene proteins. Virchows Arch. 2004;445:431-441.

20. Shia J. Immunohistochemistry versus microsatellite instability testing for screening colorectal cancer patients at risk for hereditary nonpolyposis colorectal cancer syndrome. Part I. The utility of immunohistochemistry. J Mol Diagn. 2008;10:293-300. 